\title{
Anilocra prionuri (Isopoda: Cymothoidae), a marine fish ectoparasite, from the northern Ryukyu Islands, southern Japan, with a note on a skin wound of infected fish
}

\author{
Kazuya Nagasawa, Masaya Fujimoto
}

\begin{abstract}
Anilocra prionuri Williams \& Bunkley-Williams, 1986, is reported based on a female specimen collected from the skin below the nostril of a scalpel sawtail, Prionurus scalprum Valenciennes, 1835, in the southern East China Sea off Kuchinoerabu-jima Island, one of the northern Ryukyu Islands, southern Japan. Anilocra prionuri was previously reported only from off the Pacific coast of central Honshu, Japan, but the present collection extends the geographical distribution range of the species from central Honshu southwest to the northern Ryukyu Islands and represents its first record from the East China Sea. The fish had a wound with heavily damaged epidermis at the attachment site of $A$. prionuri. It was a rare parasite of $P$. scalprum at the collection site.
\end{abstract}

Key words: cymothoid, new locality, pathology

The Ryukyu Islands are a chain of islands extending ca. $1,100 \mathrm{~km}$ from Kyushu, the southernmost major island of Japan, southwestward to Taiwan. The cymothoid fauna of the southern Ryukyu Islands has been well studied, currently consisting of six nominal species: Cterissa sakaii Bunkley-Williams \& Williams, 1986; Cymothoa pulchra Lanchester, 1902; Renocila bollandi Bunkley-Williams \& Williams, 1987; Renocila kohnoi Bunkley-Williams \& Williams, 1987; Renocila yamazatoi Bunkley-Williams \& Williams, 1987; and Ryukyua globosa Williams \& Bunkley-Williams, 1994 (Bunkley-Williams \& Williams, 1986, 1987; Williams \& Bunkley-Williams, 1986, 1994; Williams et al., 1996: Nagasawa \& Uyeno, 2012; Ishimori et al., 2013). While Williams et al. (1996) stated that three nominal species of cymothoids, Anilocra cluepei Williams \& Bunkley-Williams, 1986, Anilocra prionuri Williams \& Bunkley-Williams, 1986, and Pleopodias superatus Williams \& Bunkley-Williams, 1986, which is currently a junior synonym of $P$. diaphus Avdeev, 1975 (Hadfield
\& Smit, 2017), also occur off the southern Ryukyu Islands, these species have not been reported from the region but other Japanese waters (see Williams \& Bunkley-Williams, 1986). Contrary to the well-studied cymothoid fauna of the southern Ryukyu Islands, that of the northern Ryukyu Islands is poorly understood with only one record of C. pulchra (Nagasawa and Uyeno, 2012). Recently, we found A. prionuri, the second species of cymothoids from the northern Ryukyu Islands, where it was collected from a scalpel sawtail, Prionurus scalprum Valenciennes, 1835 (Perciformes: Acanthuridae).

The individual of $P$. scalprum infected by a large isopod was found at $5 \mathrm{~m}$ in depth by the junior author (M. F.) during his underwater ecological study of the fish species in the southern East China Sea off Yumugi $\left(30^{\circ} 27^{\prime}\right.$ $15.5^{\prime \prime} \mathrm{N}, 130^{\circ} 15^{\prime} 00.6^{\prime \prime} \mathrm{E}$, locality 5 in Fig. 2), Kuchinoerabu-jima Island, one of the northern Ryukyu Islands, Kagoshima Prefecture, on 26 August 2017. Soon after this individual was spear-fished, it was photographed on the beach 
near the sampling site, and the isopod was then taken, fixed and preserved in $70 \%$ ethanol. The specimen is deposited in the Crustacea $(\mathrm{Cr})$ collection of the National Museum of Nature and Science, Tsukuba, Ibaraki Prefecture, Japan (NSMT-Cr 25807). The scientific and common names of fishes used in this paper follow Froese \& Pauly (2018).

The isopod was found to be attached to the left side of the head below the nostril of the fish (284 mm in standard length [SL], Fig. 1A). It was a female of $A$. prionuri (Fig. 1A), $38.3 \mathrm{~mm}$ in total length and $12.9 \mathrm{~mm}$ in maximum body width, which is morphologically characterized by an elongate body with pereonite 5 being widest, a truncated anterior margin of the cephalon, endopods of uropods extending beyond the posterior margin of the pleotelson, exopods of uropods being slightly shorter than endopods, and the pleotelson with low median ridge being shield-shaped (Fig. 1A, 1C, 1D). The dorsal color of the specimen was black in life (Fig. 1A). The morphology of the specimen is identical with the description of female $A$. prionuri given by Williams \& Bunkley-Williams (1986). The known nominal spe- cies of Anilocra in Japanese waters are $A$. prionuri and $A$. cluepei: the latter species is differentiated from the former one by having a large third article in antennules and swellings on the outer and inner margins of the dactylus of pereopods 1-4 (Williams \& Bunkley-Williams, 1986).

Anilocra prionuri was originally described by Williams \& Bunkley-Williams (1986) using female specimens from $P$. scalprum (as $P$. scalprus) (type host) off Shikine-jima Island (as Shikine Island, locality 1 in Fig. 2, type locality), Miyake-jima Island (as Miyakejima, locality 2 in Fig. 2), and Seto (locality 4 in Fig. 2); and from mejina, Girella punctata Gray, 1835 (Perciformes: Kyphosidae), threadsail filefish, Stephanolepis cirrhifer (Temminck \& Schlegel, 1850) (Tetraodontiformes: Monacanthidae), and an unknown host off Seto. Recently, it was reported from $P$. scalprum off Kushimoto (locality 3 in Fig. 2, Hata et al., 2017). The reported collection localities are distributed off the Pacific coast of central Honshu, the largest major island of Japan (Fig. 2). Thus, the present collection of $A$. prionuri extends the geographical distribution range of the species from

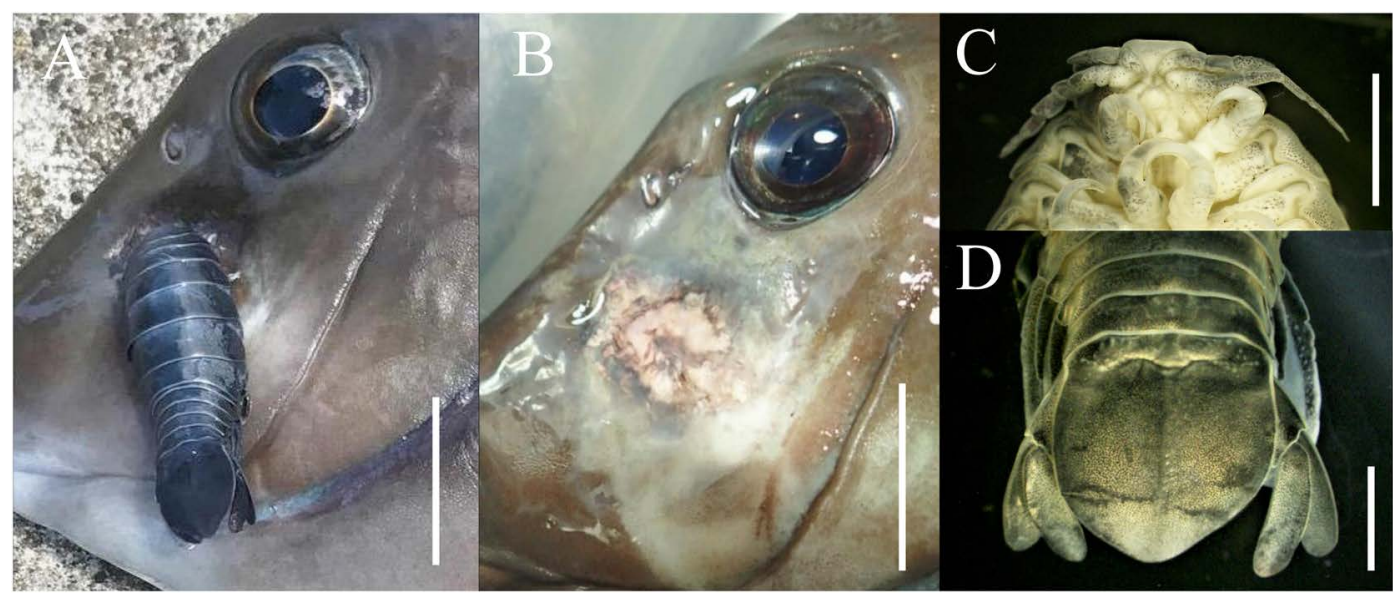

Fig. 1. A, Prionurus scalprum infected by a female of Anilocra prionuri on the left side of the head, lateral view, fresh specimen; $\mathrm{B}$, a wound below the nostril of the fish, lateral view, fresh specimen; $\mathrm{C}$, cephalon, pereonites 1-2, and pereopods 1-2 of $A$. prionuri, NSMT-Cr 25807, ventral view, ethanol-preserved specimen; D, pleon, pleotelson, and uropods of $A$. prionuri, dorsal view, ethanolpreserved specimen. Scale bars: A and B, $20 \mathrm{~mm}$; C and D, $5 \mathrm{~mm}$. 


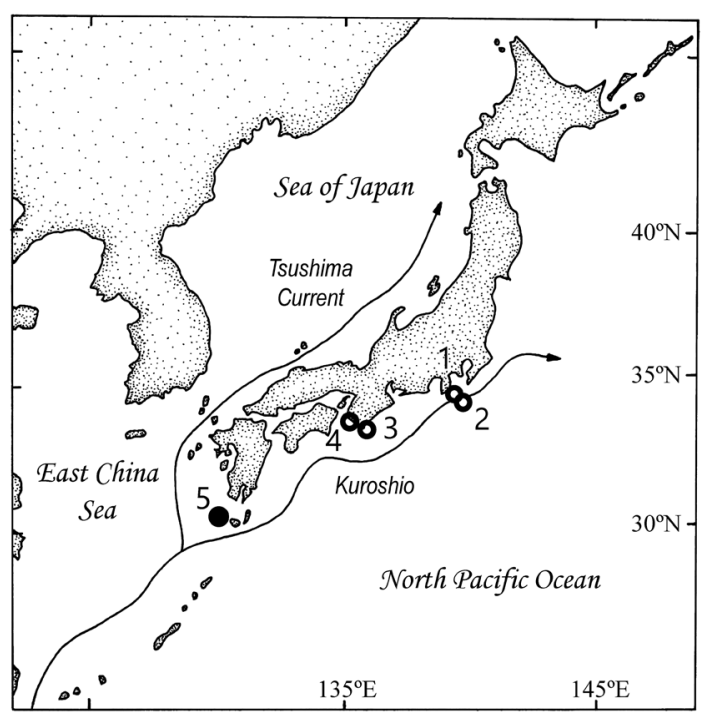

Fig. 2. Map of the Japanese Archipelago, showing the localities where Anilocra prionuri was collected in the previous (open circles) and present (closed circle) studies. Localities 1, 2, 3, and 4 are Shikine-jima Island (type locality), Miyake-jima Island, Kushimoto, and Seto, respectively (Williams \& Bunkley-Williams, 1986; Hata et al., 2017). Locality 5 is Kuchinoerabu-jima Island (this study). The routes of the warm-water current, the Kuroshio, and its branch, the Tsushima Current, are also shown.

central Honshu southwest to the northern Ryukyu Islands and represents its first record in the East China Sea. Moreover, despite the intensive survey of cymothoid isopods infecting coral reef fishes in the southern Ryukyu Islands (Bunkley-Williams \& Williams, 1986, 1987; Williams \& Bunkley-Williams, 1986, 1994), A. prionuri was not found from the region (Williams \& Bunkley-Williams, 1986: 649). Therefore, the species occurs in the northern Ryukyu Islands but does not appear to extend its distribution range to the southern Ryukyu Islands. In other words, as suggested by Williams \& Bunkley-Williams (1986), $A$. prionuri is likely to occur almost exclusively in temperate waters of Japan. The previous and present collection localities of $A$. prionuri are all strongly affected by the warm-water current, the Kuroshio (Fig. 2). While P. scalprum, which is most commonly utilized among the known hosts (Williams \& Bunkley-Williams, 1986; Hata et al., 2017; this paper), widely occurs in temperate coastal waters of Japan (Shimada, 2013), no record of $A$. prionuri is yet available from this fish species in the southern Sea of Japan affected by the Tsushima Current, a branch of the Kuroshio (Fig. 2).

The attachment site of $A$. prionuri was reported as "beneath eye or side of head of host" (Williams \& Bunkley-Williams, 1986) and "body surface" of the host (Hata et al., 2017). In the present study, the female of the species was observed to be attached firmly to the left side of the head below the nostril of the fish examined (Fig. 1A), and a wound with heavily damaged epidermis (Fig. 1B) was found at its attachment site after the isopod was removed. The wound was situated under the cephalon and anterior pereonites of the isopod and was thus most probably formed by its feeding and/ or insertion of the pereopod dactyli (Fig. 1C). Nevertheless, the wound observed in this study was not so serious as those caused by a cymothoid isopod, Nerocila phaiopleura Bleeker, 1857 on Japanese marine fishes: the host muscle of those wounds was exposed to the water and hemorrhagic (Nagasawa \& Tensha, 2016; Nagasawa \& Shirakashi, 2017; Nagasawa \& Isozaki, 2017). Based on these observations, pathological effects of $A$. prionuri on infected fishes may be weaker than those of $N$. phaiopleura.

In his underwater research in coastal waters of Kuchinoerabu-jima Island from early June to early September 2017, the junior author collected one fish infected by $A$. prionuri (Fig. 1A) and one uninfected fish (427 mm SL) with a wound on the right side of the head from more than 300 P. scalprum observed. The wound on the latter fish was similar to that observed in this study and thus considered to have been caused by $A$. prionuri. The author also did not find any fish with an isopod or a similar wound in his sample of 154 P. scalprum (210-525 [mean 388] mm SL) caught using 
gillnets or spears from the same waters from July 2016 to November 2017. These results show that $A$. prionuri is a rare parasite of $P$. scalprum in coastal waters of Kuchinoerabujima Island.

\section{Acknowledgements}

We thank Takeshi Minetoma, Toshiyuki Goto, Masayuki Yamaguti, and Kazuto Terada for their assistance with fish sampling.

\section{$\square$ Literature Cited}

Bunkley-Williams, L., \& Williams, E. H., Jr., 1986. A new species of Cterissa (Isopoda: Cymothoidae) parasitic on coral reef fishes from the Ryukyu Islands of Japan. Galaxea, 5: 203-207.

Bunkley-Williams, L., \& Williams, E. H., Jr., 1987. Three new species of Renocila (Crustacea: Isopoda: Cymothoidae), external parasites from the Ryukyu Islands of Japan. Proceedings of the Biological Society of Washington, 100: 417-432.

Froese, R., \& Pauly, D. (eds.), 2018. FishBase. (URL: http://www.fishbase.org/) (accessed 10 January 2018).

Hadfield, K. A., \& Smit, N. J., 2016. Revision of the fish parasitic genus Pleopodias Richardson, 1910 (Isopoda, Cymothoidae), with the description of a new species and key to the genus. ZooKeys, 667: 21-37.

Hata, H., Sogabe, A., Tada, S., Nishimoto, R., Nakano, R., Kohya, N., Takeshima, H., \& Kawanishi, R., 2017. Molecular phylogeny of obligate fish parasites of the family $\mathrm{Cy}$ mothoidae (Isopoda, Crustacea): evolution of the attachment mode to host fish and the habitat shift from saline water to freshwater. Marine Biology, 164: 105. DOI 10.1007/ s00227-017-3138-5.

Ishimori, H., Uyeno, D., \& Yoshino, T., 2013. Identification of two species of Amblygaster (Clupeiformes: Clupeidae) and the occurrence of a species-specific parasite Ryukyua globosa (Isopoda: Cymothoidae), from the Ryukyu Islands. Japanese Journal of Ichthyology, 60: 81-89. (in Japanese with English abstract)

Nagasawa, K., \& Isozaki, S., 2018. Three new host records for the marine fish ectoparasite, Nerocila phaiopleura (Isopoda: Cymothoidae), with a list of its known hosts. Crustacean Research, 46: 153-159.

Nagasawa, K., \& Shirakashi, S., 2017. Nerocila phaiopleura, a cymothoid isopod parasitic on Pacific bluefin tuna, Thunnus orientalis, cultured in Japan. Crustacean Research, 46: 95-101.

Nagasawa, K., \& Tensha, K., 2016. Nerocila phaiopleura (Isopoda: Cymothoidae) parasitic on Japanese Spanish mackerel Scomberomorus niphonius in the Seto Inland Sea, Japan. Biogeography, 18: 71-75.

Nagasawa, K., \& Uyeno, D., 2012. Geographical distribution affected by the Kuroshio of the fish parasite Cymothoa pulchra (Isopoda: Cymothoidae). Biogeography, 14: 151-153.

Shimada, K., 2013. Prionurus scalprum Valenciennes, 1835. In: T. Nakabo, (ed.), Fishes of Japan with Pictorial Keys to the Species. Third Edition, Tokai University Press, Hadano, p. 1619. (in Japanese)

Williams, E. H., Jr., \& Bunkley-Williams, L., 1986. The first Anilocra and Pleopodias isopods (Crustacea: Cymothoidae) parasitic on Japanese fishes, with three new species. Proceedings of the Biological Society of Washington, 99: 647-657.

Williams, E. H., Jr., \& Bunkley-Williams, L. 1994. Ryukyua globosa n. gen., n. sp., and $R$. circularis n. comb., parasitic in the opercular chambers of Pacific and Indian Ocean clupeid fishes. Journal of Aquatic Animal Health, 6: $155-161$.

Williams, E. H., Jr., Bunkley-Williams, L., \& Dyer, W. G., 1996. Metazoan parasites of some Okinawan coral reef fishes with general comparison to the parasites of Caribbean coral reef fishes. Galaxea, 13: 1-13. 


\section{Addresses}

(KN and MF) Graduate School of Biosphere Science, Hiroshima University, 1-4-4 Kagamiyama, Higashi-Hiroshima, Hiroshima 739-8528, Japan.

E-mail address of corresponding author

(KN) ornatus@hiroshima-u.ac.jp 